\title{
A Survey on Participation at Geneva's Constituent Assembly
}

\author{
Olivier Glassey \\ Swiss Public Administration Network (SPAN) and Swiss Graduate School of Public \\ Administration (IDHEAP), Route de la Maladière 21, CH-1022 Lausanne \\ Olivier.Glassey@idheap.unil.ch
}

\begin{abstract}
In February 2008 the people of Geneva voted in favor of a new Constitution to replace the current one, written in 1847 and considered by many to be out of line with today's society. The main objective of this research was to analyze participation during the process of writing a new Constitution. In the first part of this paper we set the context of our study and in the second we describe our research methodology and analysis framework. In the last section we describe our findings regarding actors and processes of participation and eParticipation, as well as underlying communication and coordination channels.
\end{abstract}

Keywords: participation, constitution, eDemocracy, framework, case study.

\section{Introduction}

Between November 2008 and February 2010 we surveyed the communication and coordination mechanisms of selected stakeholders in order to analyze participation and eParticipation at the Constituent Assembly in the Canton of Geneva in Switzerland. In previous work [1] we described our analysis framework and presented preliminary results of this ongoing research project. This current paper contains the complete results of our research.

This first section describes the context in which this study takes place, i.e. the work of a Constituent Assembly to write a new Constitution for the Canton of Geneva. The second section explains our research methodology and analysis framework; in the last part of this paper we discuss our results.

\subsection{Geneva's Constitution}

Geneva is a republic since 1535 when the city became the capital of the Protestant Reformation. The first Constitution adopted in 1543 was largely based on the "Edits Civils" written by John Calvin. Although Geneva was a French department between 1798 (when it was invaded by Napoleon's army) and 1813, it was mostly independent until joining the Swiss Confederation in 1815.

In 1846 James Fazy led a revolution that overthrew the conservative government and subsequently wrote the 1847 's Constitution that is still ruling the Canton, although it has been modified many times over that period. This text is now the oldest 
of the 26 Cantonal Constitutions in Switzerland and many believed that its language, structure and content are not adequate anymore [2].

In 1999 the parliamentary group of the "Parti Radical" proposed a bill in order to completely revise Geneva's Constitution, but without success. In 2005 an association called "Une nouvelle Constitution pour Genève" (a New Constitution for Geneva) was set up. Its front man was a famous law professor, Andreas Auer, and its members came from all political parties and from the civil society. They were ready to launch a popular initiative requiring a new Constitution as the government was reluctant to do so, but after long negotiations a vote was organized. In February 2008 the people of Geneva accepted a constitutional law allowing for a new Constitution in the Canton.

\subsection{Election of the Constituent Assembly}

In October 2008 the people of Geneva elected 80 members of the new Constituent Assembly. This was no easy task for citizens as there were 530 candidates and 18 lists to choose from. Half of these lists were presented by traditional political parties and the other nine lists represented heterogeneous interest groups (business associations, home-owners, women, retired people, and so on). Funding for the campaign was also very heterogeneous: from 5'000 Swiss Francs (about 3'500 Euros) for the women's list to 200'000 (140'000 Euros) for the business associations' list.

The quorum for a list to be elected was initially $7 \%$, but the Parliament lowered it to $3 \%$ in order to have a wider participation. However one cannot say that the initial members of this Assembly were really representative of Geneva's people: only 14 women were elected (although two elected men resigned in order to leave their position to women from the same left-wing party) and the average age of members was 56. Furthermore only three lists outside traditional parties made the quorum:

- The lobby of pensioned people (Avivo) got 9 seats; it must be said that Christian Grobet, the leader of this list, was a member of various legislative and executive authorities in Geneva from 1967 until 2005, thus this list is not completely "outside" political parties.

- The g[e]'avance list represented business and employers' lobbies and it was attributed 6 seats.

- The FAGE (Federation of Geneva's Associations) is the umbrella organization of 480 associations of all types (parents, culture, human rights, ecology, Attac, pacifism, consumers, social integration, gays, development, etc.); the associations' list obtained almost $4 \%$ of the votes (with a quorum at $3 \%$ ) and thus obtained 3 seats.

The participation rate being of $33 \%$ (about $10 \%$ less than the average participation), one can conclude that giving Geneva a new Constitution was not a popular issue and that only "traditional" or "politicized" voters accomplished their electoral duties. The political balance of the Constituent Assembly was also similar to the Parliament of Geneva: 43 seats for right wing parties and 37 for the left. 


\section{Research Methodology and Analysis Framework}

This section describes the dimensions of participation, eParticipation, and eDemocracy that we build upon them in order to define our analysis framework.

\subsection{Participation and eParticipation}

According to [3] eParticipation is an emerging research area which lacks a clear literature base or research approach. In their review of the field, they identified and analyzed 99 articles that are considered to be highly relevant to eParticipation. [3] write in their introduction that governments seek to encourage participation in order to improve the efficiency, acceptance, and legitimacy of political processes. They identify the main stakeholders of participation as citizens, non-governmental organizations, lobbyists and pressure groups, who want to influence the political system, as well as the opinion forming processes. Various information and communication technologies (ICTs) are available for eParticipation: discussion forums, electronic voting systems, group decision support systems, and web logging (blogs). However traditional methods for citizen participation (charettes, citizens' juries or panels, focus groups, consensus conferences, public hearings, deliberative polls, etc.) are still very widely used and must be taken into account when studying eParticipation.

[4] defines eDemocracy as the use of information and communication technologies to engage citizens, to support the democratic decision-making processes and to strengthen representative democracy. She furthermore writes that the democratic decision-making processes can be divided into two main categories: one addressing the electoral process, including e-voting, and the other addressing citizen eparticipation in democratic decision-making. [5] give a working definition of eParticipation as the use of ICTs to support information provision and "top-down" engagement, i.e. government-led initiatives, or "ground-up" efforts to empower citizens, civil society organizations and other democratically constituted groups to gain the support of their elected representatives.

There are many examples of surveys on eDemocracy, such as [6] who take the case of Switzerland where citizens are often called to the polls either to vote for parties and candidates or, even more often, to decide on direct-democratic votes at the three different political levels. In their paper on "smart-voting" they analyze what they call voting assistance applications, i.e. tools where citizens can compare their positions on various political issues to those of parties or candidates. They mention the Dutch "Stemwijzer" system, first introduced in 1998 and they provide in-depth information on the Swiss smartvote website.

Even if eParticipation is a relatively new research field, projects and tools are increasing thanks to governmental support [7]. Furthermore a number of research projects such as Demo-Net.org have been funded worldwide to pave the way.

\subsection{Analysis Framework}

Our main objective is to survey communication and coordination mechanisms for participation and eParticipation, thus we defined an analysis framework integrating two central variables: 
- Communication and coordination channels.

- Levels of participation.

To investigate traditional and electronic communication channels we adapted the approach used by [8] for its case study on participation and eParticipation in Germany, where he used the three arenas of political communications defined by [9]. Table 1 shows these three communications modes and the systems or actors involved in political communication, as well as the vectors used to carry this communication. We made a distinction between traditional participation vectors and ICT-enabled channels (eParticipation).

Table 1. Communication/Coordination Modes and Channels for Participation

\begin{tabular}{|c|c|c|c|}
\hline $\begin{array}{l}\text { Communication / } \\
\text { Coordination mode }\end{array}$ & System / Actors & Traditional Participation & eParticipation \\
\hline \multirow{3}{*}{ Institutional } & & Elections & eVoting \\
\hline & $\begin{array}{l}\text { Representative } \\
\text { Democracy }\end{array}$ & $\begin{array}{l}\text { Consultation: citizen } \\
\text { forums, public hearings } \\
\text { or any formal } \\
\text { consultation procedure }\end{array}$ & eVoting \\
\hline & $\begin{array}{l}\text { Direct } \\
\text { Democracy }\end{array}$ & $\begin{array}{l}\text { Voting, referendums, } \\
\text { initiatives }\end{array}$ & eConsultation \\
\hline \multirow[b]{2}{*}{ Mediated } & Mass Media & $\begin{array}{l}\text { Articles, opinions, } \\
\text { interviews, editorials, } \\
\text { readers letters, polls, } \\
\text { phone calls, etc. }\end{array}$ & \multirow{3}{*}{$\begin{array}{l}\text { Websites, forums, } \\
\text { wikis, emails, chats, } \\
\text { ePolls, webcasts, } \\
\text { social networks, } \\
\text { mobile } \\
\text { communications, Web } \\
2.0 \text {, etc. }\end{array}$} \\
\hline & $\begin{array}{l}\text { Parties } \\
\text { Interest groups } \\
\text { Trade unions }\end{array}$ & $\begin{array}{l}\text { Parliamentary groups } \\
\text { Lobbies } \\
\text { Strikes } \\
\text { Meetings, campaigns, } \\
\text { street or door-to-door } \\
\text { communication, tracts, } \\
\text { mailings, negotiation }\end{array}$ & \\
\hline Informal & $\begin{array}{l}\text { Citizens } \\
\text { Associations } \\
\text { Networks }\end{array}$ & $\begin{array}{l}\text { Street or door-to-door } \\
\text { communication, tracts, } \\
\text { free radios, local TVs, } \\
\text { cafés, clubs, etc. }\end{array}$ & \\
\hline
\end{tabular}

As for our second variable, we relied on the five levels used by [7] in their framework to assess eParticipation:

- (e-)Informing

- (e-)Consulting

- (e-)Involving

- (e-)Collaborating

- (e-)Empowerment 
We do realize the limitations of such an approach, and we agree with [10] who states that eParticipation analysis models are typically ladder type and share two assumptions: progress is equaled with more sophisticated use of technology, and direct democracy is seen as the most advanced democracy model. However we think it is useful to characterize the results of our survey.

In addition to these two main dimensions, we added the distinction proposed in the previous section by [5]: top-down initiated participation vs. bottom-up participation.

Finally we used two additional concepts in order to describe and characterize the context of participation and eParticipation:

- Process: we rely on the deliberation lifecycle defined by [11] in their comprehensive framework to analyze deliberative decision making: issue emergence, issue structuring, issue analysis, deliberation, decision, monitoring and evaluation.

- Stakeholders: we describe them according to the generic stakeholders of eParticipation workflows defined by [12]: owners, decision-makers, practitioners, moderators and participants.

\subsection{Selection of Stakeholders and Methodology}

In order to apply our analysis framework, we selected a sample of stakeholders involved in institutional, mediated and informal communication:

- The "Parti Radical Genevois" (PRG) is a progressive right-wing party that has a long history in Geneva; it was born in 1841-42 during the first revolutionary movements in the Canton and it was led by James Fazy, the author of the 1847's Constitution that is still in effect today. We selected it because PRD is rather representative of traditional parties and political structures.

- "Les Verts" are Geneva's green party. It was founded in 1983 by various members of environmental and anti-nuclear associations. The Green party is now a well-established party with, amongst others, two elected members of the executive government in Geneva (which comprises seven ministers). We decided to survey them because they are a newer party, created by members of the civil society and based on a more associative operational mode.

- We already introduced the Federation of Geneva's Associations (FAGE) in section 1: it is the umbrella organization of 480 associations. We integrated them in our study because they are very typical of networked communication and participation.

- The "Tribune de Genève" (TDG): we chose it because it is Geneva's main printed newspaper and it furthermore provides a blog platform to its readers; most blogs related to the Constituent Assembly are hosted at the TDG.

- The Communication Bureau of the Constituent Assembly: this is the official communication channel of the Assembly.

- The Plenary Assembly, where deliberation and decision-making takes place.

This survey is qualitative and based on two investigation methods: 
- Periodical review of secondary sources: all identified websites, blogs, forums, wikis, and publicly available working documents related to the Constituent Assembly.

- Semi-structured interviews with representatives of the stakeholders listed above.

We used a standardized interview guide (with adaptations when necessary, e.g. when interviewing elected members or "outsiders"). It was based on the following questions:

- How do you prepare plenary sessions of the Constituent Assembly?

- How do you make decisions (e.g. regarding voting at plenary sessions)?

- How are you organized regarding participation / consultation of your members? Of citizens?

- How do you manage documents and information produced by the Constituent Assembly?

- How do you communicate around your work?

- Do you use information and communication technology for your work (mail, wiki, office suites, document servers, blogs, etc.)?

- Do you see any opportunities for eParticipation at the Constituent Assembly?

\section{Results}

In this section the results of our survey are presented according to the dimensions we defined in our analysis framework. We will not go into the details of our analysis and we will try to highlight only the key findings.

\subsection{Communication and Coordination Channels in Participation}

We will use the dimensions defined in Table 1 to describe our findings in terms of communication and coordination channels.

On institutional participation: the Constitutional Assembly's first task was to define its own operational rules, as the constitutional law did not contain any information on execution. These rules defined several innovative possibilities (in comparison to standard parliamentary policies in Switzerland). They allowed several interesting participatory tools:

- Petitions: any person or group can submit a proposal to the Constituent Assembly under the form of a petition; petitions are transferred to the relevant thematic commission that then decides whether they want to take it into account.

- Collective proposals: a proposal signed by at least 500 citizens has to be handled by the relevant thematic commission and should be answered in a chapter of the commission's report; at the time of writing, around 20 collective proposals were submitted.

- Public hearings: the Assembly can hear any representative of the civil society or of interest groups, as well as members of the public sector from Geneva, and from other Cantons or countries; this concept of public hearing 
did not previously exist in Switzerland, where hearings are privately held in commissions.

- Plenary Assembly: all members, commissions, groups or circles can make proposals and submit amendments. Minutes of the plenary sessions are published

- Thematic commissions: 5 thematic commissions (fundamental rights, political rights, institutions, territory, roles of the State and finance) as well as a coordination commission were set up. They work on thematic content and can organize hearings (private or public) and they already provided preliminary reports.

- Groups: all members elected on a list belong to a common group; each group received funding for a parliamentary assistant; an elected member that would quit his group could not take part in thematic commissions anymore; groups can be heard at the plenary assembly upon request.

- Circles: elected members that have common interests can form a circle; circles must be formed of at least three members; members can be part of several groups; circles can be heard at the plenary assembly upon request; for the time being there are circles dedicated to sustainable development, youth, SMEs, and culture.

Although several innovative participation channels were defined there is no eParticipation at the institutional level. However bottom-up participation is supported, mainly with collective proposals and petitions. Institutional communication is quite traditional, although press releases, minutes and thematic reports are published online.

On mediated participation:

- Parties: The "Parti Radical Genevois" has only one participation channel, the Caucus, where elected members and the party's leaders define their positions. "Les Verts" also have a Caucus operating in a similar way, and they additionally work with so-called "resources groups" where members of the party debate and make recommendations on given issues. The "FAGE" has set up several participation channels: colloquiums or meetings where any member of the 480 federated organizations can attend and make their opinion known; competence poles that are organized similarly to resources groups mentioned above; common objectives, where a minimal and common set of requirements for all 480 associations is defined.

- Media: The local press, radio and TV provide minimal coverage of the Constituent Assembly, and it does not seem to raise much interest. However the blog platform of the "Tribune de Genève" is very active, with around 20 elected members and one group having their own blog. Furthermore two or three elected members comment the plenary sessions on Twitter; one of them even launched a contest to propose an introduction to the new Constitution. Last, the main source of information and place of exchange on the Constituent Assembly is a blog called "La Gazette de la Constituante" maintained by a journalist of the "Tribune de Genève".

- Interest groups, associations: Most of the collective proposals mentioned above were initiated and supported by these groups. 
Here again several interesting participation channels were developed, but eParticipation is still rather limited: one blog platform and a few "tweets". In parties we found mainly top-down supported participation, with the exception of the FAGE where bottom-up participation is made possible through the possibility of colloquium's attendance for any member of any represented association.

On informal participation: few citizens comment on the blogs and follow the "tweets" mentioned above. Participation channels remain very traditional with the possibility of submitting a petition or of signing a collective proposal.

\subsection{Levels of Participation}

In Fig. 1 we positioned our various stakeholders regarding their participation level and their participation approach. This graph is given as an indication only, as it was not created on the basis of quantitative indicators, but rather on the author's perceptions, e.g. the mass media is typically a top-down informing process, elected members that have a blog or use Twitter are informing on a more bottom-up basis, the FAGE supports involvement through colloquiums, and so on.

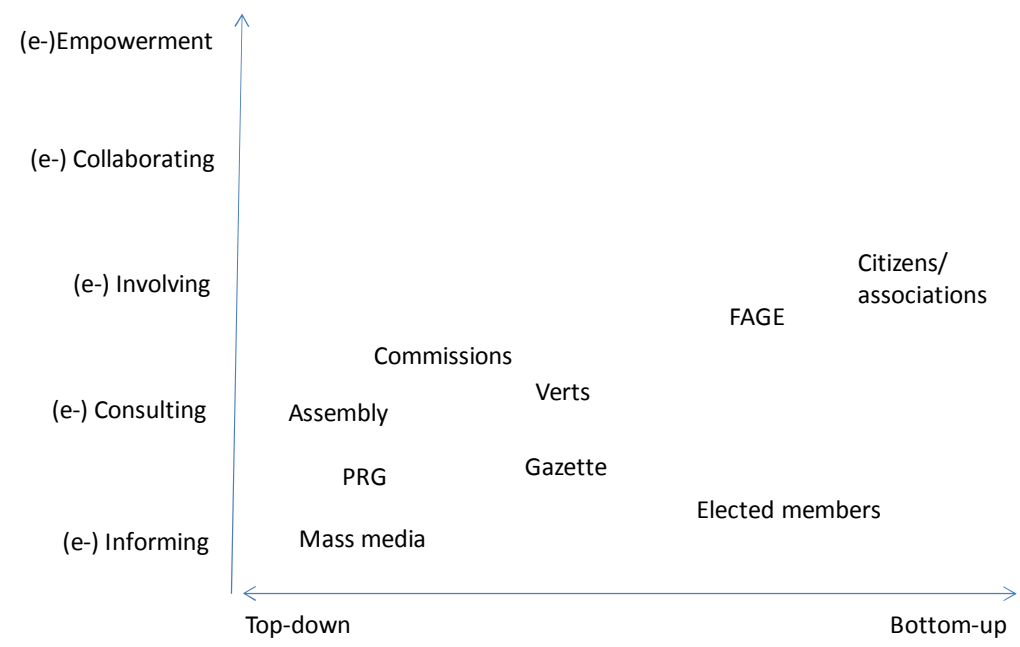

Fig. 1. Stakeholders positioning regarding participation levels and participation approaches

With a quick look at this figure one can conclude that the main supported participation processes are informing and consulting, and barely involving. We are thus quite far from our "ideal" participation where all stakeholders could be empowered.

\subsection{Stakeholders and Processes in Participation}

Table 2 is an effort to characterize stakeholders in terms of the typology defined by [12]. We have already defined what commissions, groups and circles were in $\S 3.1$ and others such as media and citizens are quite self-explanatory. Let us briefly explain some additional stakeholders listed in the table: 
- The Presidency is made of four members elected by the Constituent Assembly and it is mainly in charge of applying rules and monitoring the operations of the Assembly (and of signing acts).

- The Bureau is formed of one delegate per group of the Constituent Assembly and is mainly responsible for planning, organizing, budgeting external relations.

- The General Secretary supports the work of the Constituent Assembly; it comprises legal and administrative workers that are hired by the Assembly.

Table 2. Participation at Geneva's Constituent Assembly in terms of Actors and Tasks

\begin{tabular}{|c|c|c|}
\hline Stakeholders & Description & Tasks \\
\hline Owners & Citizens & Vote and elections \\
\hline Decisions-makers & Elected members & $\begin{array}{l}\text { Debate and vote in plenary } \\
\text { sessions }\end{array}$ \\
\hline Practitioners & $\begin{array}{l}\text { Bureau, General } \\
\text { Secretary, Presidency, } \\
\text { Commissions, Groups, } \\
\text { Circles }\end{array}$ & $\begin{array}{l}\text { Organize tasks of Constituent } \\
\text { Assembly and prepare } \\
\text { proposals }\end{array}$ \\
\hline Moderators & Media, experts & $\begin{array}{l}\text { Comment on Assembly's work } \\
\text { and provide input (e.g. in } \\
\text { public hearings) }\end{array}$ \\
\hline Participants & $\begin{array}{l}\text { Citizens, associations, } \\
\text { interest groups }\end{array}$ & $\begin{array}{l}\text { Prepare petitions or collective } \\
\text { proposals }\end{array}$ \\
\hline
\end{tabular}

Table 3 characterizes the participation channels described in $\$ 3.1$ regarding the deliberation life-cycle defined by [11].

Table 3. Participation and Deliberative Processes at Geneva's Constituent Assembly

\begin{tabular}{llll}
\hline Process & Instruments & Description \\
\hline Issue emergence & $\begin{array}{l}\text { Petitions, collective } \\
\text { proposals }\end{array}$ & $\begin{array}{l}\text { Any person or group can } \\
\text { submit ideas }\end{array}$ \\
$\begin{array}{l}\text { Issue structuring } \\
\text { Issue analysis } \\
\text { Commissions, Circles, }\end{array}$ & $\begin{array}{l}\text { Commissions prepare } \\
\text { proposals under the forms of } \\
\text { articles or general principles; } \\
\text { groups and circles can be heard } \\
\text { by the Bureau upon request; } \\
\text { the Assembly can hear any } \\
\text { representative of the civil } \\
\text { society, interest groups or } \\
\text { public authorities. } \\
\text { The Assembly deliberates on } \\
\text { proposals and amendments. } \\
\text { Decision are made by majority } \\
\text { rule }\end{array}$ \\
Deliberation & Plenary sessions & Plenary sessions & \\
Decision & N/A &
\end{tabular}




\section{Conclusion and Future Work}

This survey was conducted in an exploratory mode, as the Constituent Assembly was just elected when we began and nothing was in place. Indeed during the first months elected members did not even have an email address and there was no secretary or any support staff. As sessions went along, the Assembly defined its own policies and operational rules. Before we started our survey we had the analysis framework defined in Table 1, and when new requirements appeared we added variables such as levels and approaches of participation, processes and stakeholders.

We believe this context of a Constituent Assembly to be very interesting to investigate participation, as it is rather different from many projects where citizens participate on generic societal issues or very specific topics such as local territorial planning. Indeed, the redaction of a new Constitution really resides at the heart of democratic processes. Our key findings were not so much of a surprise: participation was made mainly through institutional channels with a top-down approach (such as public hearings and thematic consultations); although some interesting bottom-up and mediated channels were set up, most notably the collective proposal. Moreover, eParticipation was rather limited, with a number of elected members using a blog or Twitter to communicate.

As our analysis framework was build in an exploratory manner and suited for a specific context, it needs to be refined and validated in order to be more generic. Along with partners from Switzerland and Germany we are currently preparing a research proposal on participation at the local level and this will be a perfect test-bed to do so.

\section{References}

1. Glassey, O.: Writing a New Constitution for Geneva: An Analysis of Participation Mechanisms. In: Tambouris, E., Macintosh, A. (eds.) Electronic Participation, Proceedings of Ongoing Research, ePart 2009, 1st International Conference, Linz, Austria (2009)

2. Schmitt, N.: Quelques réflexions comparatives à propos de l'élection d'une assemblée constituante à Genève (2008),

http://www.federalism.ch/files/Newsletter/742_19/constituant e-geneve.pdf

3. Sanford, C.S., Rose, J.: Characterizing eParticipation. International Journal of Information Management 27, 406-421 (2007)

4. Macintosh, A.: Characterizing e-Participation in Policy-Making. In: Proceedings of the 37th Annual Hawaii International Conference on System Sciences, HICSS-37 (2004)

5. Macintosh, A., Whyte, A.: Evaluating how eParticipation changes local democracy. In: Irani, Z., Ghoneim, A. (eds.) Proceedings of the eGovernment Workshop. Brunel University, London (2006)

6. Ladner, A., Felder, G., Schädel, L.: From e-voting to smart-voting - e-Tools in and for elections and direct democracy in Switzerland. IDHEAP Working Paper 4/2008 (2008)

7. Tambouris, E., Liotas, N., Tarabanis, K.: A Framework for Assessing eParticipation Projects and Tools. In: Proceedings of the 40th Annual Hawaii International Conference on System Sciences, HICSS-40 (2007) 
8. Mambrey, P.: From Participation to e-Participation: The German Case. In: Janowski, T., Pardo, T. (eds.) Proceedings of the 2nd International Conference on Theory and Practice of Electronic Governance (ICEGov), Cairo, Egypt (2008)

9. Habermas, J.: The Theory of Communicative Action. Beacon Press, London (1981)

10. Grönlund, A.: ICT Is Not Participation Is Not Democracy - eParticipation Development Models Revisited. In: Macintosh, A., Tambouris, E. (eds.) ePart 2009. LNCS, vol. 5694, pp. 175-185. Springer, Heidelberg (2009)

11. Passas, A.A., Tsekos, T.N.: A Procedural Model for Public Deliberation. In: Tambouris, E., Macintosh, A. (eds.) Electronic Participation. LNCS, vol. 5694, Springer, Heidelberg (2009)

12. Colombo, C., Kujnstelj, M., Molinari, F., Todorovski, L.: Workflow Modeling for Participatory Policy Design: Lessons form Three European Regions. In: Macintosh, A., Tambouris, E. (eds.) Electronic Participation. LNCS, vol. 5694. Springer, Heidelberg (2009) 